\title{
Deconstruction of Discernment in Child Euthanasia
}

\author{
Elia R.G. Pusterla ${ }^{1,2}$
}

Received: 12 February 2020 / Revised: 10 June 2021 / Accepted: 12 July 2021 /

Published online: 20 September 2021

(c) The Author(s) 2021, corrected publication 2022

\begin{abstract}
Belgian law on child euthanasia uses the concept of discernment to bestow the right to die to minors. Jacques Derrida's deconstruction of oppositional logic grasps the ambiguity of this use of discernment and generally challenges the alleged force of a textual sign meaningfully to differentiate itself from its different and meaningless else. This alleged ability to discern the presence of discernment impinges the truthvalue of the distinction between worthy/unworthy lives. The resulting undecidability morally suggests the respect for otherness and promotes the moral value of the suspension of arbitrary judgment (epokhe $\bar{e}$ ) and, in so doing, de facto converges towards the praxis of the doctrine of the sanctity of life that embraces the 'life is always quality' argument.
\end{abstract}

Keywords Discernment - Deconstruction - Bioethics $\cdot$ Child euthanasia $\cdot$ Derrida Undecidability $\cdot$ Truth-value $\cdot$ Suspension of judgement (epokhē)

\section{Introduction}

This article investigates the recent use of the concept of discernment in the field of bioethics. Discernment implies differentiation, but this is not always possible and represents 'a very serious problem' (Gregory, 2019: 1), as when it may come to legal mindreading aiming at 'judgements as to what mental states other individuals were in at a particular point in time' (Gregory, 2019: 1). Accordingly, deconstruction of the Belgian law on child euthanasia displays the use of discernment to ground unacceptable moral arbitrariness. Accordingly, Jacques Derrida allows showing how this use of discernment determines undecidability (Derrida, 2010a, b: 252). The latter constitutes a moral value that excludes the truth-value of euthanasia options such

Elia R.G. Pusterla

elia.pusterla@supsi.ch

1 European Institute, LSE, London, England

2 DEASS, University of Applied Sciences and Arts of Southern Switzerland, Manno,

Switzerland 
as those promoted by this Belgian law and de facto positively embraces the praxis of the 'life is always quality' argument.

In February 2014, Belgian Parliament promulgates, and King Philippe signs, the 'Loi modifiant la loi du 28 mai 2002 relative à l'euthanasie, en vue d'étandre l'euthanasie aux mineurs' - extension of the 2002 euthanasia law. This law confers the right to die to minors under given conditions of sickness and suffering, as well as of conscience at the moment of the formal request and of discernment (Philippe Roi des Belges, 2014). Juristically, the right to die is not universally extended, raising questions concerning the attribution criterion. The law provides that the request of a minor patient to access the right to die needs the approval of a (child) psychologist asked to collect information about the patient's medical case [dossier médical], examine him/her, and attest in a written form the discernment of the minor patient [le discernment du mineur]. Therefore, the use of the concept of discernment as the central criterion to determine the legal provision of the right to die raises questions concerning its reason(s) and appropriateness (Van Assche et al., 2019). This account emerges in particular under the Belgian senate's display of the notion of discernment:

\begin{abstract}
'Selon la définition légale des auteurs de la proposition, l'euthanasie ne concerne que les mineurs disposant de la capacité de discernement. Pour rappel, la capacité de discernement n'est pas un état absolu dont disposerait une personne à partir d'un certain âge et pour le reste de sa vie, pour toute situation vécue. Elle est évaluée pour chaque individu, face à une situation particulière. Elle doit être attestée pour chaque question nouvelle' (Sénat de Belgique, 2013).
\end{abstract}

Discernment is thus very explicitly defined as not absolute but relative; uncertain but possible; unnecessarily permanent and definitive but temporary; particular and not universal; subjective but objectively assessable. Therefore, rather than confirming a consolidated practice, this rappel opens up to the logical uncertainty described by Derrida's undecidability between opposites (1981). ${ }^{1}$ The here applicability of such a notion raises the general issue on the risk of foundational groundlessness in the alleged use of discernment by given pieces of law. In this particular case, and given the above description of discernment, it even before amazes that sensitive bioethics provisions depend on its assessment. Taking responsibility for legislating in such a delicate matter imposes the presence of an adequate logic whose ground has to resist a deconstructionist screening. The latter, indeed, represents an exigent philosophical test bench ${ }^{2}$ for value judgments with truth-value ambitions (Sim, 2019:

\footnotetext{
1 'One often associates the theme of undecidability with deconstruction. [...] The undecidable is not merely the oscillation between two significations [...] or the tension between two decisions. Undecidable - this is the experience of that which, though foreign and heterogeneous to the order of the calculable and the rule must nonetheless - it is of duty [devoir] that one must speak - deliver itself over to the impossible decision while taking into account of law and rules'(Derrida, 2010a, 2010b: 252).

2 'A decision that would not go through the test of the ordeal of the undecidable would not be a free decision; it would only be the programmable application of the continuous unfolding of a calculable process. It might perhaps be legal: it would not be just' (Derrida, 2010a, 2010b: 252).
} 
5). Indeed, although postmodernism is in general liable to have complicated ethics (Mordacci, 2017: vii-xiii), deconstruction rests upon and places an undeniably 'ethical demand' (Critchley, 2014: 1) on the justification of ideological and political choices that many would gladly do without (Sim, 2019: 5-6 \& 101). Accordingly, it is notable that a secular assembly attributes centrality in complex matters of bioethics to a slippery concept typically loaded with religious connotations and traditionally raising philosophical and metaphysical debates with clear-cut ontological and epistemological positions. Discernment is, for instance, a recurring theme and instrument of the Christian/Catholic tradition, especially in Jesuits' moral theology and spirituality, who practice the exercise of discernment between good and not good things, often following St. Ignatius of Loyola's legacy. As a Jesuit, the Catholic Pope Francis adopts particular attention to discernment, regularly referring to and emphasising it in theological, pastoral and doctrinal spheres. By considering this Christian/Catholic tradition, the political choice of relying so sharply upon discernment to set up (child) euthanasia may even seem somehow provocative, or at least paradoxical, antinomical. The Christian use of discernment is indeed supposed to lead to different ethical choices and practices that promote and apply the doctrine of the sanctity of life and categorically exclude euthanasia. Given such distance and tension between the implications associated with different uses of this same concept, it is necessary to determine whether there is a justified and substantial difference between them. Moreover, it becomes crucial to assess whether the first sort of antinomy due to these uses of discernment, to support even opposite rationales and prescriptions upon the (moral) lawfulness of euthanasia, does not shift towards a second and more severe one. The latter would consist, indeed, in using discernment as if it were different from, and devoid of, metaphysical grounds and implications that support its use within patterns of moral prescription such as the religious one, though it is not. It is, therefore, necessary to qualify the logical ground of this secular use of the notion of discernment promoted by the Belgian state. In all likelihood, the juristic use of discernment is also common to other private and public law legislation in Belgium as in other countries. However, such particular - and possibly paradigmatic - use of discernment appears problematic given the premises of its ambiguous definition above. Indeed, even supposing that, in principle, discernment would matter to bestow the right to die, it is surprising that such sensitive issue as child euthanasia - which further exacerbates debates on euthanasia tout court - is so frontally handled through the use of discernment which is, at this point, expected to guarantee complete reliability and not an instead additional reason for juristic ambiguity (Van Assche et al., 2019). Belgian law on child euthanasia thus represents a case in point called to assess the logical ground of this use of discernment to settle sensitive bioethical questions and the values that such use brings about.

\section{Discernment's Procedural Problems}

The use of discernment fundamentally asks for an ontological effort to understand whether it is possible to agree on what discernment is. If the presence of discernment is the attribution criterion of the right to die, such epistemological 
exercise requires an ontological ground. The latter calls back the disputes between realists, conceptualists, nominalists, nihilists, and other trains of philosophical thoughts on the existence of universals. What is thus to be looked for when aiming to assess someone's discernment?

This question raises a twofold problem concerning the availability of method and moral implications. Theoretically, the definitional ambiguity of discernment could be circumvented procedurally. Within moral theories, there is an opposition between realist and constructivist ontologies of moral values (Mordacci, 2003: 24), where the second one claims for a fair procedure allowing for social recognition of independent and impersonal moral values (Rawls, 2003; Veca, 2010: 49). Socially built and regardless of direct experience of the surrounding reality, moral values could arise from a fair process of reflexive equilibrium and reasonable deliberation. The applicability of principles deriving from such a constructivist approach could justify both the formulation of the above rappel and the current form of the child euthanasia law. Discernment would remain fleeting yet legally accessible and applicable through a fair procedure bypassing the ontological challenge (Mordacci, 2003: 24).

Nevertheless, this solution is unavailable due to law procedural limits. Logically, in two out of four cases, the external advice provided by a (child) psychologist could produce unfair outcomes concerning the patient's request. The external adviser could assess the presence of discernment correctly and accept or reject the minor's request, but the opposite scenario is also possible, and the presence of discernment could be wrongly processed. Even excluding the many-sided (also symbolic) form of violence of psychological inspection - especially whether incorrect - the procedural reliability of the law further decreases as a function of parental mediation. The law does not allow children to have the discernment to access the right despite the parental veto. The right to die could be denied on this basis, regardless of the presence of discernment. This point is not to contest parents' moral and legal responsibility but to wonder whether the legislator realises how the law discriminates minor patients on a parental basis and irremediably jeopardises the argument that the law applies to those deserving it.

Another procedural problem derives from the (child) psychologist's role and deontological position. Are such experts ready to take charge, legally and morally, of wrongly processed request? If so, is it appropriate to put them in such a professional position? Does this responsibility affect their will and capability to perform the profession? Otherwise, who else would be willing and able to answer for faulty processed cases? Any procedural attempts to bypass the ontological issue on discernment feed a vagueness concerning involved actors' legal (and moral) responsibility. Therefore, the child euthanasia law cannot result as relying upon constructivist moral values - such as those shaping John Rawls's 'egalitarian liberalist' (Kymlicka, 1999) theory of justice that benefits from the availability of a fair procedure. Procedurally, the law guarantees neither the assessment of discernment nor the claimed centrality of that concept to bestow the right to die. Consequently, there must be - and is to be investigated - another ground resorting to other logical (and moral) arguments. 


\section{Discern Discernment through Discernment}

The Belgian legislator posits discernment as a relative, uncertain, temporary, particular, and subjective condition - state, état - that is at the same time attestable pour et face à chaque nouvelle question. This assumes discernment as real and assessable, repérable and evaluable (Sidgwick, 2011 [1874]). Discernment is, therefore, loaded with ontological presuppositions philosophically located somewhere between realism and conceptualism (Gratton, 2014: 15). Specialists are expected to discern concrete situations of medical cases with varying complexity. This requires compatibility between the immanent cases to be processed and the transcendent notion of discernment to refer. However, can the presence of discernment be precisely and incontrovertibly detected despite relative, uncertain, temporary, and other similar conditions? An easy answer to this epistemological issue could be that everybody may agree that discernment, although fleeting, is fundamentally ascribable to the ability to perform what the Latin verb dis-cernerre describes: to see distinctly and differentiate, distinguish, choose through separation. Discernment is indeed the ability to distinguish the difference between something and something else unequivocally different, between what is discernment and what is not, or its else. The claim that discernment requires the ability to dis-cernerre presumes the existence of difference, the availability and possible use of a faculty and unambiguous way - and correlative will (Deleuze, 2004: 168) - of reading them. This implies an epistemological presupposition concerning the existence of both language and literacy in respect of the real, meaningful, and intelligible (textual) signs to read. Accordingly, any medical case is readable thanks to a comparison based on the existence of a language allowing correct interpretation of a 'con-text' written through a language of signs having its readability. The latter implies the conviction on the existence of discernible signs overcoming any sort of Hamletic doubt that symbolic logic would translate into the difference between $\mathrm{X}$ ('This is discernment') and $\sim$ ('This is not discernment'). Discernment would allow discerning what is discernment from what is not, namely its logical negation.

Fundamentally, the law affirms the possible evaluation of individuals' ownership of discernment thanks to the prior assumptions of a language, its potential readability, and the presumption of actuating that potentiality. The law formally shapes a tautological doubling since the ability to assess someone's discernment is claimed by saying that someone's discernment is assessable. The assessment of discernment would depend on the ability to read the sign(s) correctly in compliance with the assumption that any 'con-text' - such as a medical case - allows for unambiguous readability thanks to an unambiguous language. Indeed, (child) specialists may investigate patients' discernment only where something like discernment exists. All cases compare to the transcendental universals concerning someone's life, but in particular to someone's ability (and will) of correctly using discernment and reading the con-textual language. Consequently, the issue integrates a meta-ethics dimension concerning the presence and correct use of discernment to assess the true value of life - and thus allowing access to a legal right. 
Therefore, the universals in this language to decipher are both knowledge and value, particularly in the twisted relational form of a patient's knowledge of the value of life. This imbrication has a twofold consequence. First, the patient must acknowledge the correct value of his/her life. Second, the (child) psychologist must assess the patient's correct knowledge of such value and assess the worthlessness of someone's life only under a prior idea of why the patient's knowledge of the value of his/her life is correct. The right to die access becomes a matter of conformity with knowledge of the value of life the (child) psychologist is supposed to assess thanks to his/her expertise correctly. The specialist claims the realist/conceptualist ability to assess the patient's discernment, depending on what the patient knows and thinks about his/her condition. This corresponds to say, 'If you do (not) read the situation this way, you are (not) discerning', and tautologically, there is (no) discernment since one is (not) discerning. In principle, such evaluation overcomes the just medical assessment of the patient's health and incorporates a broader assessment of the knowledge of the value of (the rest of) his/her life. This possibly includes issues of personal values, attitudes, and hopes. ${ }^{3}$ As far as formally granted by this law, the child psychologist inspects the patient's reasons for living and their correctness. Indeed, the right to die could lapse regardless of a dreadful medical state because either the candidate's motivations or presumed perspectives of life could lead the child psychologist to determine accordingly. The expert, vice versa, may certify that either given reasons are good reasons to bestow the right or that future events do not leave any reason to deny it. In both cases, the evaluation of the presence of discernment rests upon the comparison of valuable universals to the immanent condition of someone's life.

The law thus inescapably raises issues of reliable ontology for two reasons. First, it is uncertain whether patients' requests will be processed identically. Indeed, only some of them could be charged with undiscerning the true value of the rest of their life. Second, child psychologists may also emphasise different aspects to assess single requests. The emendatory possibility that more psychologists, or even a forum, intervene to decide in this regard may reduce but not eliminate at their roots such problems. Therefore, child psychologists not only own a relevant discretionary power but attest the 'truth value' of any patient's life following this logic:

\begin{tabular}{lllll}
\hline $\begin{array}{l}\text { Minor patient's } \\
\text { request }\end{array}$ & $\begin{array}{l}\text { Tautological value } \\
\text { of life assessed } \\
\text { by the patient }\end{array}$ & $\begin{array}{l}\text { 'A' child-psychologist } \\
\text { assessment } \\
\text { of discernment }\end{array}$ & $\begin{array}{l}\text { 'B' child-psychologist } \\
\text { assessment } \\
\text { of discernment }\end{array}$ & $\begin{array}{l}\text { Provision of } \\
\text { the right to die }\end{array}$ \\
Case 1 & A $\vee \sim \mathrm{A}$ & $\mathrm{T}$ & $\mathrm{T}$ & Yes \\
Case 2 & $\mathrm{B} \vee \sim \mathrm{B}$ & $\mathrm{T}$ & $\mathrm{T}$ & Yes \\
Case 3 & $\mathrm{A} \vee \sim \mathrm{A}$ & $\perp$ & $\perp$ & No \\
Case 4 & $\mathrm{~A} \vee \sim \mathrm{A}$ & $\mathrm{T}$ & $\perp$ & $?$ \\
\hline
\end{tabular}

\footnotetext{
3 In this respect, among other things, the reliability of minors could be biased by their looking for adults' approval despite fear, or even to comfort them - not to mention the simple fact that age matters in respect to the presence of a theory of mind putting minors and adults on the same cognitive level, with truly shared conceptual notions (Gregory, 2019: 3).
} 
Cases 3 and 4 respectively illustrate the two cases discussed above. Either the same cases (Cases 1 and 3) produce different assessments, or different assessments (Case 4) freeze the provision of the right to die. Finally, there is no specific and limited type of cases that can access the right (Cases 1 and 2). Accordingly, the question remains open on how general readability and literacy (and personal competence over them) can be presumed.

The assessment of discernment cannot rely on the presence of a fair procedure and risks dealing with the non-derivable and tautological notion of discernment. These problems may be familiar to other pieces of law than the Belgian one on child euthanasia. However, it is hard to compare the effects of these problems, given the delicate context of bioethics. Knowing that for (i) classical scepticism ' $[t]$ ruth [...] was to be treated as a relative rather than an absolute concept - with all the difficulties that brought in its train' (Sim, 2019: 5), and that (ii) such stance 'cannot easily be dismissed as philosophical game playing' (Sim, 2019: 5), things get complicated. A law of such ethical significance must provide a sound theory of the language determining the distinction between $\mathrm{X}$ and $\sim \mathrm{X}$ and a valuable justification for its choice and use. In this regard, one must necessarily consider that 'many contemporary philosophers have adopted that stance of relativism, arguing that language is too imprecise to guarantee the truth of anything we say' (Sim, 2019: 5). '[F]ollowers of deconstruction and the work of the French poststructuralist Jacques Derrida' (Sim, 2019: 5) emphasise textual polysemy and how meaning is 'to be considered in a constant state of flux, altering subtly from statement to statement over time - and from participant to participant in the process of discourse' (Sim, 2019: 5). This position may not necessarily be correct in a general and absolute sense. However, it is imperative to establish with complete certainty that it is not valid and pertinent in this particular law case. Indeed, although ' $[\mathrm{t}]$ he implications of such position for politics and ideology are quite alarming, in that apparently we can never aspire to absolute truth in our value judgments' (Sim, 2019: 5-6), the bioethical and moral nature of the values at stake by this law do not allow for discounts of any kind. Value judgments of this magnitude cannot run the risk of being based only on 'relative certainty' (Sim, 2019: 119).

Consequently, the law necessarily needs a universal notion of discernment to hope for justification of that presumption of assessing the 'truth value' of minor patients' requests to gain access to the right to die. Thus, this investigation requires going through the possible deconstruction of the oppositional else, allowing one to distinguish between $\mathrm{X}$ and $\sim \mathrm{X}$. The hypothesis is that there will not be such an else if not as arbitrariness whose reason(s) and aim(s) pertain to a provocative act of illiteracy.

\section{Worthy Life and Else}

Possible arguments stating that one can intuitively agree on the presence of discernment should not only carefully consider criticisms upon intuitionism such as Henry Sidgwick's (2011 [1874]) and Rawls' (2003), but also and foremost Derrida's movement of différance 'that makes the thinking of it uneasy and uncomfortable' 
(Glendinning, 2011: 58). Derrida's movement of différance deals with the 'affirmation of dissemination in terms of the non-reducible plurality of different understandings of the same text' (Glendinning, 2011: 57). Once agreed that assessing a medical case compares to reading a text, there is yet no guarantee of being confronted to a readable one, whose language would have a single and absolute meaning and readability (Derrida, 2016 [1974]). The logic grounding the conviction of ability to discern between meaningful $\mathrm{X}$ and its else, or the presence/absence of discernment is to deconstruct here since '[i]t is a matter of judging what permits judgement' (Derrida, 2010a, b: 231) and see the origin and plausibility of that alleged readability. Accordingly, Derrida hypothesises on the origin of the alleged difference between $\mathrm{X}$ and its else, thereby helping to avoid apriorisms. The '[...] 'stricture' of différance, [...] is extended by Derrida to every organism, organization, corpus, and movement. Every being-together, Derrida states, 'begins by binding-itself, by a binding-itself in a differential relation to itself', (De Ville, 2010: 57). For Derrida, this process typically applies to law, its legitimacy, as to signs, their meaning and interpretation:

'[...], it is always a matter of differential force, of difference as difference of force, of force as différance or force of différance (différance is a force différée-différente); it is always a matter of the relation between force and form, between force and signification, of 'performative' force, illocutionary or perlocutionary force, of persuasive force and of rhetoric, of affirmation, of signature, but also and above all, of all the paradoxical situations in which the greatest force and the greatest weakness strangely exchange places [s'échangent étrangement]' (Derrida, 2010a, b: 235).

Derrida's deconstruction of the oppositional logic through the notion of différance raises the question of the presumed force of a textual sign to meaningfully differentiate itself from the allegedly meaningless opposite, its else. Reading X's meaning asks for X's force to absolutely differentiate itself from the absolute $\sim \mathrm{X}$. $\mathrm{X}$ is absolutely opposite relatively to its else $\sim \mathrm{X}$, and that given $\mathrm{X}$ must be absolutely different from any given $\sim X$, at any time. Therefore, the possibility of having a readable $\mathrm{X}$ becomes a matter of what appears to represent a corresponding absoluteness, as the oxymoronic 'relative absoluteness'. Derrida's différance grasps the polysemic dissemination of different meanings, depending on the essential act of differre having temporal implications constituting differences (Ferraris, 2008). Simon Glendinning explains:

'[...] a 'singular event' that functions as a means of communication (e.g. an event of speech) can be the event it is only on condition of a necessary or structural relation to an iteration that is another such singular event which is not present at the time of its production or reception, another event which is not what it is except in its relation to another such event, another such event which is not what it is except in relation to another such event' (Glendinning, 2011: 71).

This potentially never-ending regression allowing unambiguous readability of a text assumes the temporal iterability of an oppositional logic according to 
which $\mathrm{X}$ can differentiate itself from $\sim \mathrm{X}$, all the time, all-time, every time (Derrida, 2005: 13). Indeed, unambiguous readability presumes the possibility of a meaningful sign that does not risk future meaninglessness. $\mathrm{X}$ may absolutely oppose $\sim \mathrm{X}$ only if it is sure that nothing will question the ontological certainty of that opposition. Therefore, unambiguous readability needs to declare the reading and interpretation time ended and performs a final judgement. Derrida's reading of the parricidal killing of Cronus by Zeus reveals how the final judgment expresses the sovereign character and derivation of law precisely under its presumed mastery over time:

'It is by winning out over time, by putting an end to the infinite order of time, so to speak, that he asserts his sovereignty. One might take this formulation to the extreme, to the point where it touches the end of time, touches the finitude or the finity of time, touches sovereignty as the instant of a decision that, at the indivisible point of its action, puts an end to time, as well as to language' (Derrida, 2005: 17).

Hence, the reading of a text can be meaningful only in respect to such ability to anticipate and neutralise possible appearances of meaninglessness since becoming absolute, final, in-finite, thus beyond temporality and eternally 'out of time'. The correct reading of the difference between $X$ and $\sim X$ requires the presumed ability to freeze, and free it from, the temporal dimension. Consequently, a judgement on $\mathrm{X}$ 's meaning implies the claim of a presumed ability to assess the a-temporal ultimate absoluteness of $\mathrm{X}$ that stops depending on any oppositional antagonism to any particular $\sim X$. Hence, $X$ presumes the prophetic ability to consider the future time in order to come to its determination and, paradoxically, exists now while being eternally out of time. In these terms, the only possibility of an unambiguous reading of a text becomes aporetic since it requires declaring there is no text anymore, or nothing to read anymore. The unambiguous reading of $\mathrm{X}$ affirms the principle of being able to stop (and elude) time and declare X's potentiality as over, as in a declaration of death. However, the latter arises 'the question of the criterion allowing one to declare death, that someone is dead, and it is not an easy question today' (Derrida, 2014a: 72), neither logically and scientifically nor politically (Agamben, 1998: 93). Derrida does not think that meaningfulness is strictly impossible but that it is just never absolute or final. Texts can be meaningful, but this meaning must be open to revision at a future time, as in the case of a translation or interpretation of a text that can improve over time. ${ }^{4}$ Conversely, the conception of the possibility of unambiguous readability of a given text $\mathrm{X}$ imposes the need to produce a correct value

\footnotetext{
4 As per a historical perspective, regardless of the questionable quality and goals of revisions (Prosperi, 2021: 46-49), it is essential to distinguish between the 'living existence' of a text and the 'further time' of its interpretation/revision. In principle, indeed, any condition of life of the text - even once it is finally thought of as dead or destroyed and gone lost - can result in further interpretations and narratives (even in the form of mythological and legendary tales). On this basis, the total independence between the living conditions of a text and the ever further possibility of interpreting it makes the motion to the destruction of the text itself even more unjustified and incomprehensible (unless the purpose is not instrumental to perhaps attempt conditioning its historical interpretation itself (Prosperi, 2021: passim)).
} 
judgement concerning both the current and future absolute rightness of the reading itself.

The question the Belgian law raises explores how and when a textual reading achieves such unambiguity. This problem reflects in, and affects, the political dimension as per William Connolly's description of politics as an 'ambiguous and relatively open-ended interaction of persons and groups who share a range of concepts but share them imperfectly and incompletely' (Connolly, 1993: 6). At stake is the secular credibility of the law and its compatibility with a political theory favouring social (and religious) pluralism and not dogmatic towards difference - perhaps fearing that otherness is not a defining factor but an identity threat, and in particular to the idea of X's absoluteness (Connolly, 1999). Therefore, the Belgian law must explain and justify the perspective of meaning, the language allowing absolute differentiation between a life $\mathrm{X}$ and its opposite $\sim \mathrm{X}$ ( and how and when $\mathrm{X}$ becomes $\sim \mathrm{X}$ and how to recognise this change occurrence).

\section{Reading (Unreadable) Signs and Sanctity of Life}

The Belgian law claims that life, once and for all, may assume forms no longer defensible at any cost and deserving the right to die for minors able to understand it with discernment. The logic of the law bases on the alleged possibility of establishing with discernment that a particular $\mathrm{X}$ is opposed to $\sim \mathrm{X}$. It affirms that a minor can adequately distinguish between a life worthy of being lived or not; for a life $\mathrm{X}$ worthy of being lived, his/her opposed $\sim \mathrm{X}$ life is not and will never be worthy and so deserves not being (unnecessarily) prolonged. Thus, the Belgian law operates a qualification of someone's life by distinguishing between $\mathrm{X}$ and $\sim \mathrm{X}$, thus nuancing the linear application of the sanctity of life principle. James Rachels (1986) is considered the leading promoter (Ruddick, 2005) of this approach to the utilitarian moral theory (Mordacci, 2003: 116-130) through the distinction between biological and biographical lives. Rachels contests anyone's tendency to dread his/her death and to necessarily see it as a source of evil and distinguishes between complete/incomplete lives by indicating that the real tragedy associated with someone's death depends on the incompleteness, futility, and unfulfilled promise (Rachels, 1986: 48-51) in respect of what a given life could have been otherwise. Knowing that people are:

'beings who have hopes, aspirations, and desires that may or may not be ful-

filled; we need to consider them as the subjects of lives with possibilities that may or may not be realized. Something may be bad for a person, not only because it causes unhappiness, but because it disappoints a hope, or precludes a possibility for his life' (Rachels, 1986: 49).

Rachels emphasises potentialities, and death becomes a contingent tragedy because "when a person dies, not merely some, but all his hopes, aspirations, and desires are frustrated, and all the possibilities for his life are cancelled' (Rachels, 1986: 57). Rachels's approach to the doctrine of the sanctity of life applies when it deals with records of people who 'may remain alive long after one's life is over' (Rachels, 1986: 56). People living in a state of apparently irreversible coma 
or other conditions of severely damaged physical and mental conditions cannot experience hopes, aspirations, and desires, and their biological death would not constitute that tragedy. The relative simplicity and lack of mental complexity - where complexity equals a positive acceptation meaning admirable sophistication and elaborateness - of mentally disabled individuals decrease the sorrow of their death. Accordingly, by envisaging situations of forced choice, Rachels states:

'[I]f you must choose between the death of the retarded person and the death of the normal person - there is reason to choose in favour of the normal person. The reasoning is exactly the same as in the earlier comparison: where the life of the mentally more complex creature is at issue, there are more reasons why the death would be a bad thing. [...] Although we may be inclined to endorse 'the equal worth of all human lives' almost by reflex - it sounds so noble, who could deny it? - not many of us really believe this high-sounding principle' (Rachels, 1986: 58).

The more life is intellectually sophisticated, the more its end represents a tragedy, especially when many hopes, aspirations, and desires are frustrated. 'Complexity matters because, when a mentally complex being dies, much more can be said about why its death was a bad thing' (Rachels, 1986: 57). The hermeneutical grounding of Rachels's rationale is that someone's life is valuable if and when someone else can say something about it and recognise something valuable in it, particularly about the meaning of that life. Following Rachels's logic, people manifestly endowed with discernment - be they children or adults - should not have the biographical value of their life challenged. However, Rachels's introduction of a normative principle based on a semantic approach potentially extends the detection of different worthiness of lives $\mathrm{X}$ and $\sim \mathrm{X}$ universally. Though all are forms of biological life, only those biographical are meaningful and deserve the application of the sanctity of life principle. Rachels proposes a perspective of sense, a language that distinguishes between signs $\mathrm{X}$ and $\sim \mathrm{X}$ of valuable/non-valuable lives and a different reading would not be compliant with the correct use of discernment that should read accordingly. Still, being this rationale a matter of language, with the interpretation of its signs, it is compulsory to question the grounding logic and origin of that language. Indeed, the political problem exposed by Connolly's agonism on the different and incomplete understanding and sharing of concepts (and meanings) within a pluralist society applies. Any possible qualification of the sanctity of life principle must avoid the risk of resting upon arbitrary conventionalism, particularly unacceptable in ethics (Anscombe, 1958: 11). Rachels's position is particularly controversial given the origin of the distinction on the 'meaning of life'. Peter Gratton explains:

'As Rousseau notes [...], prior to reason, human beings have an interest in their well-being and self-preservation along with a "natural repugnance to seeing any sentient being, and especially any being like ourselves [nos semblables], perish and suffer' (Rousseau, 1987: preface, par. 9). At such an early stage, who is this 'we' and how does one distinguish the semblable and the non semblable?'(Gratton, 2012: 41) 
This analysis leads one to interrogate the origin of the judgment that someone's conditions of life are less meaningful than another's. Supposing that human beings have such interest in their well-being and repugnance for others' suffering indeed, there is no guarantee of at least avoiding hurried readings of the meaninglessness of others' lives by applying what the Catholic Pope Francis calls a 'false compassion' (Francis, 2014), ${ }^{5}$ due to wrong distinctions (Francis, 2014). Francis's position is frontally opposed to Rachels's because it denies the very possibility of qualifying life:

'Many think that quality of life is linked mainly to the economic possibilities, to the wellbeing, to the beauty and enjoyment of physical life [...]. But in reality, to the light of faith and right reason, human life is always sacred and always quality. There is not a human life more sacred than another: every human life is sacred! Just as there is not a human life qualitatively more significant than another, only by virtue of means, rights, and more social and economic opportunities. [...] [H] uman life is always sacred, of value, and inviolable, and as such must be protected and cared for' (Francis, 2014).

While both Rachels and Francis ascribe to life an inviolable character, their positions substantially diverge in the qualification of life to given human conditions. The saddle point depends on the presence of given signs of life and the meaning to them attributed. The Catholic position considers any form of life as always being of quality and that any (sign of) life is intrinsically communicative and meaningful. Rachels's qualification of the sanctity of life doctrine adopts a different perspective and addresses a fundamental problem of understanding under which conditions life is, becomes, and remains meaningful and thus inviolable.

The idea of a quality variable asks to determine whether it rests upon a correct distinction between life and its life else. Suppose that life's meaningfulness legitimises the application of the sanctity of life principle, to what does a meaningful (sing of) life correspond? The main concern derives from the question about those signs proving biographical presence and their origin. What does constitute life's sacredness?

Rachels's distinction between biographic and biological lives evokes Giorgio Agamben's reading of Aristotelian (Aristotle, 2009 [350 BC]) distinction between ' $z o \bar{e}$ - the simple fact of living common to all living beings (animals, men, or gods) - and the bios - [...] the form or way of living proper to an individual or a group' (Agamben, 1998: 9). Agamben's zoê/bios distinction is the cornerstone within the polis to distinguish between phone and logos: 'It is not by chance, then, that a passage of the Politics situates the proper place of the polis in the transition from voice to language. The link between bare life and politics is the same link that the metaphysical definition of man as 'the living being who has language' seeks in the relation between phonē and logos' (Agamben, 1998: 12).

\footnotetext{
5 ' $[\mathrm{I}] \mathrm{t}$ seems that what decreased is the will of taking care of the human being, especially when suffering, weak, and vulnerable' (Francis, 2014).
} 
As for Rachels's emphasis on the communicative relevance and linguistic intelligibility of a biography, Aristotle's emphasis on $\log o s$ as a human peculiarity assumes the relevance of meaningfulness, thus going beyond beastly simplicity and meaningless phone. The latter does not entail an accomplished form of communication since it is a primordial sound with no trace of structured language with its intelligible meaning. In order to be meaningful, communication requires the intelligible use of a language. People unable to express themselves through such intelligible signs do not communicate (and could perhaps not even be considered 'human' people at all, or anymore), and theirs would only be biological lives. At least, those lives would not deserve the efforts prescribed by applying the sanctity of life principle to guarantee their inviolability. Thus, the unit of measurement to assess the meaningfulness of life consists of someone's ability to produce communicative and intelligible signs. Biographical lives could be assessed by those literate persons able to read correctly the presence of meaningful signs (thus proving their making use of discernment). We have thus come to the metaphysics of presence (Derrida, 2016 [1974]).

The tautological circularity applicable to the 'discernment of discernment' applies here concerning the intelligibility of the signs of meaningful lives. Life is meaningful in the presence of meaningful signs, and life is sacred in the presence of 'signs of sacredness'. Nevertheless, the 'biographical approach' puzzle consists of the absence of an unambiguous ontological definition of the unit of measurement of its rationale, or the meaning of that graphé, that meaningful sign in appraising someone's life. Could the solution be to emphasise the ability and the will to produce a communicative sign? Supposing this solution pertinent, however, Rachels's logic does not allow any inference on either. Rachels's unit of measurement does not solve the hermeneutic problem on the definition and interpretation of signs and their intelligible distinction. It does not ultimately explain why the lives of people in a coma, or the deaths of mentally disabled individuals, would be less significant, meaningful, and communicative than other peoples; nor it explains how a healthy person can absolutely succeed in performing a communicative sign. 'As Derrida put it, meaning never attained 'full presence'. Such is the strange 'being' of the sign' (Sim, 2019: 5). Still less, it explains why (underage) persons able to communicate his/ her desire to die should be indulged rather than helped and encouraged to convince themselves of their meaningfulness. It means that the assessment of the presence and use of discernment runs the risk of embarking on a road in which the only resignation about having reached an alleged state of life no longer biographical would correspond to the appropriate use and presence of discernment. Rachels's statement that less 'can be said about why [...] death was a bad thing' (Rachels, 1986: 57), reveals an interpretative apriorism whose empirical correspondence is judgemental and ontologically fleeting. Affirming that someone's life loses any value when given conditions may deprive that person 'of a life in a deeper sense' requires stronger criteria than meaninglessness and unintelligibility of signs not ascribable to the conventional language of hopes, aspirations, and desires (Rachels, 1986: 53). Since the issue is euthanasia - child euthanasia particularly - and pain therapy perhaps a viable or at least helpful alternative, it is unclear who can establish that a (minor) patient asking for the right to die must be satisfied by considering his/her biography 
over. Indeed, intelligibility - the use of the intellect and intelligence itself - calls for the exercise of the function of inter legere, or a 'read in between' that is 'the ability to understand the existing nexuses between the varied moments of the experience' (Cortellazzo \& Zolli, 1998: 607). In this regard, Derrida deconstructs the sharp distinction between $z o \bar{e}$ and bios by affirming that '[...] the distinction between bios and $z o \bar{e}-$ or $z \bar{e} n$ - is more than tricky and precarious; in no way does it correspond to the strict opposition on which Agamben bases the quasi totality of his argument about sovereignty and the biopolitical in HomoSacer [...]'(Derrida, 2005: 24). Derrida does not even see a sharp distinction between phone and logos. He not only contemplates meaningless uses of the language and communication (Derrida, 2005: 101), but also questions the 'onto-theological' origin of the link between (intelligible) speaking and meaning in order to show the distinction between phone and logos - whose logocentrism allowed 'the possibility of symbolism in general (before the distinction between man and animal, and even before the distinction between the living and the nonliving)' (Derrida, 2010a, b [1967]: 247). Moreover, other robust philosophical traditions attribute to our (conventional and interpretative) decisions the origin of the meaning of words and conceives language as a 'human product' (Wittgenstein, 1958: 184-185).

Rachels's semantic approach neglects how the con-textual object of investigation, or the interpretandum (Gadamer, 2004 [1960]), puts pressure on the heuristic tools used to approach it, literally the prejudice, rather than the opposite. Prejudices' natural potential to grasp the otherness' knowledge risks becoming an interpretative 'provocation' that wants to stop the time of interpretation by declaring it finished arbitrarily. There is a fundamental implication depending on how the prejudice approaches the interpretandum. Any pre-judicial distinction between $\mathrm{X}$ and $\sim \mathrm{X}$ must be interrogated to continue the constantly ongoing knowledge of the interpretandum (Gadamer, 2004 [1960]: 396). Therefore, the prejudice must interrogate (and simultaneously be interrogated by) the interpretandum without becoming a provocation aimed at judging while ignoring, or perhaps precisely because of it. This auspice is not a defence of con-textual hypertextuality - such as that which de facto postpones (i.e. differs) the access to the ultimate meaning of the interpretandum by assuming the presence of a still (and perhaps only now) inaccessible mystery. Instead, it is a defence of the existential dignity of the text itself qua existing entity, against the risk of a pretence that pretends - and de facto prevents - contextual reading because of a provocation that arbitrarily interrupts the time of interpretation, declares that there is no more text, and, to get rid of any doubt, destroys it. This provocative interrogation of the interpretandum opposes the desire for possible knowledge but is just a pretended knowledge resting upon (ill-concealed) nothingness and aggressive embarrassment perhaps due to a tautological inability to comprehend: 'Yes, bêtise consists in wanting to conclude' (Derrida, 2009: 161). ${ }^{6}$ Undoubtedly, this is a temporal 'urgency that obstructs the horizon of knowledge' (Derrida, 2010a,

\footnotetext{
${ }^{6}$ Derrida uses this unique and untranslatable French word betise to merge stupidity and (inhuman?) bestiality (Derrida, 2009).
} 
b: 255). Indeed, such a pretence does not know whether $X$ and $\sim X$ are different, but does not hesitate to proceed anyhow and provokes to see who will resist that 'pretence', as when tempting. Thus, the presence of an absence (of the meaning) is surreptitious and without foundation, and the Belgian law reveals metaphysics of presence in the unproven affirmation of an absence of meaning: 'If one gives the name 'provocation' to the strategy that compels the potentiality of Law to translate itself into actuality, then his is a paradoxical form of provocation, the only form adequate to a law that is in force without signifying [...].' (Agamben, 1998: 37). Derrida's approach to sacredness:

'In Derrida's analysis, 'faith' and the 'sacred' testify to an immune form of 'otherness'. Both faith and sacredness only ever affirm the prior relevance of an un-encompassable otherness that surpasses relations with all things. Both of these concepts demand faith in a wholly other and thus remain wholly immune. The consequences of this reading show that it is not strictly an otherworldly claim, nor can it provide justification for any analysis or existential assertion of divinity. Instead, it designates the essential vulnerability and fragility of this world as it comes to be it becomes otherwise, in whatever way that may be' (O’Connor, 2010: 83).

The assessment of the religious character of Derrida's thought, and his approach to sacredness, are in this instance irrelevant to settle the debate on whether Derrida is a 'radically atheist' (Hägglund, 2008) or unconventionally religious (Caputo, 1997), nor to assess the religious connotation of auto-immunity itself (Hägglund, 2008; Sherbert, 2011). Derrida's approach to sacredness is of primary importance here for the use of discernment by the Belgian law on child euthanasia and how it articulates ethically. Indeed, Derrida's whole deconstructionist project and relative approach to justice, truth, and knowledge undoubtedly has an ethical dimension which expresses the moral value of the suspension of judgment (epokhe ) in opposition to the risk of value judgments devoid of truth-value. ${ }^{7}$ This aims to oppose the unjustified violence possibly inherent to the law (Kilgore, 2005) by revealing the ontological vulnerability of things regarding the coming event represented by unknown and unforeseeable otherness. It is not a matter of deciding what is sacred, but of the possibility of sacredness by recognising and protecting the present unknown through which the possibility of any future and unexpected - since unknown - event of knowledge always occurs:

'It is not a matter of speaking time but of letting the other, and thus of giving the other, $[\ldots]$, it is a matter of leaving the other not only speech, but of letting time speak, the other's time, what its time, the time of the other, has as most proper to it. It is the time that one must let speak, the time of the

\footnotetext{
7 Derrida explains the Epokhe of the rule (Derrida, 2010a, b: 251) as it follows: 'This is something that happens sometimes; it happens always in part and according to a parasitizing that cannot be reduced by the mechanics or the technology introduced by the necessary iterability of judgments' (Derrida, 2010a, b: 251).
} 
other, rather than leaving the other speaking time. It is a matter of letting the time speak, the time of the other in what is most proper to the other, and therefore in the other is most other - and which happens, that I let happen, as time of the other, in the present time of 'my' poem. And that I let happen, that I let happen what happens (of the other) - this letting neutralises nothing, it is not a simple passivity, even if some passivity is required here: it is on the contrary the condition for an event to advene and for something to happen' (Derrida, 2009: 234).

The point is the recognition of the sacred character of any as unknown as a possible future event. The future is always other, different than expected. Deconstruction stems from that sacredness and positively seeks to be its guarantor:

'A decision begins with the initiative to read, to interpret, and even to calculate. But to make such a decision, one must first of all experience what Derrida calls 'undecidability.' One must experience that the case, being unique and singular, does not fit the established codes and therefore a decision about it seems to be impossible. The undecidable, for Derrida, is not mere oscillation between two significations. It is the experience of what, though foreign to the calculable and the rule, is still obligated. We are obligated - this is a kind of duty - to give oneself up to the impossible decision, while taking account of rules and law' (Lawlor, 2016).

Therefore, the positive recognition of undecidability, and the relative suspension of the (arbitrary) value judgement, have a 'sacred' moral posture to be affirmed and defended. This constitutes explicitly and expresses the moral character of Derrida's deconstructionist understanding of the suspension of judgment (epokhē) based on the normative force of the unknown as such. Indeed, efforts on the part of a subject to maintain conditions of openness ${ }^{8}$ towards the unknown through epokhe take on, and intrinsically have, a moral value to the extent that one attributes it to the epistemological credibility of the alleged distinction between certainty and belief (Caputo et al., 2005: 30) - especially within the logical framework of political agency and relative laws aiming at secular standards.

\footnotetext{
8 ' $[\ldots]$ Derrida does argue that openness to the future is the condition of possibility of the event, of identity, of decision, responsibility, hospitality, and in general the relation to the other, concepts that make up the normative commitments of democracy to come. The identity of a responsible subject, as well as the event of decision, is established only by way of a productive and differential repetition from an openended future. This future in turn installs an originary otherness, a certain undecidability, in the very fabric of identity and the event. Every 'subject' and every moment in time has always already been opened to the other (that is, to otherness in general, as manifested, for instance, by personal others). So the event of decision as well as agency and identity are not possible without the absolute futurity of time. It is both the condition of possibility as well as the condition of impossibility of the conditioned in its metaphysical or traditional purity: while it makes the presence of subjectivity and of every moment in time possible, it also introduces an originary otherness that renders this presence unstable and compromised, shot through with an absence that, Derrida claims with Heidegger, the Western tradition, including the tradition of political thought, forgot to think' (Fritsch, 2002: 583).
} 


\section{Presumption and Provocative Illiteracy}

The Belgian law on child euthanasia's presumed assessment of discernment reveals the presence of provocative illiteracy. This leads one to see how deconstruction comes to ethical positions de facto compatible with the praxis associated with Francis's 'life is always quality' approach, rather than its biographical qualification. Both Francis's and Rachels's positions look at con-textual lives through the metaphysics of presence, of possible sense or non-sense, respectively. However, only the second presumptuously claims an indeed unproven scientific knowledge and language that arbitrarily imposes the end of the text and destroys it by declaring its dynamis over and preventing any further reading. Accordingly, Derrida reminds that:

'Even in the most theoretical act of any scientific community [...], any organization of the social bond refers to an act of faith beyond or in spite of all sorts of evidence. 'I believe' or 'believe me', 'sworn faith' is at the same time a social bond, economic bond, credit, as well as truthfulness is the presupposition of truth' (Derrida, 2014b: 23).

By no coincidence, Rachels articulates his argument in terms of faith when he states that 'not many of us really believe this high-sounding principle' (Rachels, 1986). Instead, the deconstruction of this only apparently secular use of the (religiously loaded) concept of discernment by the Belgian law on child euthanasia reveals the applicability and heuristic pertinence of biblical hermeneutics, mainly deriving from the Pericope Adulterae. As for Jesus's notorious statement 'He that is without sin among you, let him be the first to cast a stone at her' (St John, 2013 [70-100 AD]: verses 8:7), a deconstruction of the Belgian law puts all the pressure on those presuming the ability and right to interpret and apply the law rather than on those perhaps breaking it. By introducing a comparative criterion suggesting that the one who would be sine peccato - thus sacred, or saint - could feel free to enforce the law, the unnoticeable difference, in-difference, between them is emphasised. Who can proclaim his/her sanctity before the law ${ }^{9}$ ? It is impossible to distinguish between innocent and guilty, or between $\mathrm{X}$ and $\sim \mathrm{X}$, because, at the bottom, the selfpresumption of innocence is intrinsically guilty or, at best, naïve. As if this 'Sacred text' would explain how and why the text is sacred.

What is at stake in the alleged use and assessment of discernment in the Belgian law on child euthanasia is the honesty of admitting that some undecidability reigns supreme over anyone's life that is readable as meaningful or meaningless as that of anyone else's. The provocative presumption that characterises this law and the possible adoption of a biographical approach to justify it should, therefore, give way to a conscious attitude of acceptance of the other for what it is. People ready to

\footnotetext{
9 'It follows from that paradox that at no time can one say presently that a decision is just, purely just (that is to say, free and responsible), or that someone is just, and even less, 'I am just'. Instead of just one can say legal or legitimate, in conformity with a law, with rules and conventions that authorize calculation, but with a la of which the founding origin [l'origine fondatrice] only defers the problem of justice' (Derrida, 2010a, b: 252).
} 
assess other lives' meaninglessness should consider their ability to convince about the meaningfulness of their own life. Who can claim the unconditional meaningfulness and biographical nature of his/her life? Nobody's life may be read as 'meaningless' unless it is agreed that any life could also be similarly judged as meaningful, with no possibility of having particular distinctions between $X$ and $\sim$ X. Given these premises, no text can be suppressed in the name of an arbitrary claim for lack of textuality, not even when this comes from the text itself. Therefore, Francis's linear application of the doctrine of the sanctity of life de facto converges with the moral attitude derivable from the deconstruction of the law in question. Derrida's assessment of undecidability would not make him the promoter of the doctrine of the sanctity of life stricto sensu (Caputo et al., 2005: 30-31). The defence of the text reached through deconstruction does not imply an act of faith in the now unapparent sense of things but frontally recognises the injustice of the present judgments arbitrarily denying it (and surreptitiously acting accordingly). Thence, as emerged, given the unavoidable condition of having to decide while not knowing on what basis to make such a decision, Derrida positively proposes a solution of deciding to welcome the other (Critchley, 2014: 87): this is the moral (and demanding) value of the suspension of value judgments. Therefore, on his part, there is the profound ethical and moral refusal to intervene arbitrarily without the availability of proven knowledge. This attitude of honesty and humility is not the same as that of a Pope who welcomes the divine and mysterious character of life and its path since there is no theology to support it. However, deconstruction inevitably excludes the option of acting with justice by destroying the other, given the mentioned undecidability. To fully understand the moral importance of the suspension of the judgment, it is vital to remember the indispensable value of the inseparability between justness and justice. 'In any case, this implication of the fault of judgment, where judgement is not only the determinative judgment that leads to the true or the false, but rather the judgment of the judge, the judgment form which one expects some justness as well as some justice' (Derrida, 2009: 149).

Therefore, the Belgian law on child euthanasia is problematic for both logical and moral reasons and does not represent the right product of secular politics. Consequently, the fact that 'the amendment that was passed is, in many ways, a toneddown version of the initial proposal and, indeed, of many possible alternatives discussed' (Raus, 2016: 312) is not ethically relevant. The law brings about the provocative presumption of doing what it does not, or discerning discernment and judging what is unread and even allows stopping the time for reading and interpretation. This falls into a casuistry that does not interrogate its way of defining, for instance, what is intelligible, or that does not interrogate itself about its adequate literacy but clumsily promotes provocative illiteracy.

Funding Open access funding provided by University of Applied Sciences and Arts of Southern Switzerland (SUPSI).

Open Access This article is licensed under a Creative Commons Attribution 4.0 International License, which permits use, sharing, adaptation, distribution and reproduction in any medium or format, as long as you give appropriate credit to the original author(s) and the source, provide a link to the Creative 
Commons licence, and indicate if changes were made. The images or other third party material in this article are included in the article's Creative Commons licence, unless indicated otherwise in a credit line to the material. If material is not included in the article's Creative Commons licence and your intended use is not permitted by statutory regulation or exceeds the permitted use, you will need to obtain permission directly from the copyright holder. To view a copy of this licence, visit http://creativecommons.org/ licenses/by/4.0/.

\section{References}

Agamben, G. (1998). Homo Sacer: Sovereign Power and Bare Life. Stanford University Press. Anscombe, G. E. M. (1958). Modern Moral Philosophy. Philosophy, 33, 1-19.

Aristotle, . (2009). 350 BC. Translated by Ernest Barker, Oxford, Oxford University Press.

Caputo, J. D. (1997). The Prayers and Tears of Jacques Derrida - Religion without Religion. Indiana University Press.

Caputo, J. D., Hart, K., \& Sherwood, Y. (2005). Epoché and Faith: An Interview with Jacques Derrida. In Y. Sherwood \& K. Hart (Eds.), Derrida and Religion: Other Testaments. Psychology Press.

Connolly, W. E. (1993). The Terms of Political Discourse. Princeton.

Connolly, W. E. (1999). Why I Am Not A Secularist. London, University of Minnesota Press.

Cortellazzo, M., \& Zolli, P. (1998). Dizionario Etimologico della Lingua Italiana. Zanichelli.

Critchley, S. (2014). The Ethics of Deconstruction: Derrida and Levinas. Edinburgh University Press.

De Ville, J. 2010. Sovereignty without sovereignty - Derrida's Declarations of Independence In: BARBOUR, C. \& PAVLICH, G. (eds.) After Sovereignty - On the question of political beginnings. London \& New York: Routledge

Deleuze, G. (2004). Difference and Repetition. Continuum International Publishing Group.

Derrida, J. 2013 [1981]. Plato's Pharmacy In: DERRIDA, J. (ed.) Dissemination. Translated, with an Introduction and Additional Notes, by Barbara Johnson. London: Bloomsbury. pp. 67-121.

Derrida, J. (2005). Rogues: Two Essays on Reason. Stanford University Press.

Derrida, J. (2009). The Beast \& the Sovereign - (Vol. I). University of Chicago Press.

Derrida, J. (2010). Force of Law - The "Mystical Foundation of Authority." In G. Anidjar (Ed.), Jacques Derrida - Acts of Religion. Routledge.

Derrida, J. (2010). 1967. Writing and Difference.

Derrida, J. (2014a). The Death Penalty - (Vol. I). The University of Chicago Press.

Derrida, J. (2014). Quel che il Signore disse ad Abramo. Castelvecchi.

Derrida, J. (2016). 1974. Baltimore, Johns Hopkins University Press.

Ferraris, M. (2008). Introduzione a Derrida Meastri del Novecento. Edizioni Laterza.

Francis, J. M. B. (2014) To participants in a commemorative conference of the Italian Catholic Physicians' Association on the occasion of its 70th anniversary of foundation. Conference of the Italian Catholic Physicians' Association, 15th November 2014. https://www.vatican.va/content/francesco/ en/speeches/2014/november/documents/papa-francesco_20141115_medici-cattolici-italiani.html. Accessed 14 May 2019

Fritsch, M. (2002). Derrida's Democracy to Come. Constellations, 9, 574-597.

Gadamer, H.-G. 2004 [1960]. Truth and Method, Continuum - Bloomsbury

Glendinning, S. (2011). Derrida - A Very Short Introduction. Oxford University Press.

Gratton, P. (2012). The State of Sovereignty - Lessons from the Political Fictions of Modernity SUNY series in contemporary French thought. State University of New York Press.

Gratton, P. (2014). Speculative Realism - Problems and Prospects. Bloomsbury.

Gregory, D. (2019). Judging the mental states of others: 'mindreading' in legal decision-making (pp. 1-15). First Published Online.

Hägglund, M. (2008). Radical Atheism: Derrida and the Time of Life. California, Stanford University Press.

Kilgore, C. D. (2005). Review Essay: Jacques Derrida: Acts of Religion. Iowa Journal of Cultural Studies, 7, 106-108.

Kymlicka, W. (1999). Les théories de la justice. La Découverte.

Lawlor, L. 2016. Jacques Derrida. In: Zalta, E. N. (ed.) The Stanford Encyclopedia of Philosophy. Fall 2019 Edition: https://plato.stanford.edu/archives/fall2019/entries/derrida/. Accessed 31 May 2019. 
Mordacci, R. (2003). Una introduzione alle teorie morali - Confronto con la bioetica Campi del sapere. Feltrinelli.

Mordacci, R. (2017). La Condizione Neomoderna. Einaudi.

O'Connor, P. (2010). Derrida: Profanations, Continuum Studies in Continental Philosophy. Continuum.

Philippe Roi Des Belges 2014. Loi modifiant la loi du 28 mai 2002 relative à l'euthanasie, en vue d'étendre l'euthanasie aux mineurs. In: Belgique, E. D. (ed.). Institut Européen de Bioéthique.

Prosperi, A. (2021). Un tempo senza storia - La distruzione del passato Vele. Giulio Einaudi Editore.

Rachels, J. (1986). The End of Life - Euthanasia and Morality. Oxford University Press.

Raus, K. (2016). The Extension of Belgium's Euthanasia Law to Include Competent Minors. Journal of Bioethical Inquiry, 13, 305-315.

Rawls, J. (2003). A Theory of Justice - (Revised). The Belknap Press of Harvard University Press.

Rousseau, J.-J. (1987). Discourse on the Origin of Inequality. The Basic Political Writings. Hackett.

Ruddick, W. (2005). "Biographical lives" revisited and extended. Journal of Ethics, 9, 501-515.

Sénat De Belgique 2013. Proposition de loi modifiant la loi du 28 mai 2002 relative à l'euthanasie en vue de l'étendre aux mineurs. Le Sénat de Belgique.

Sherbert, G. (2011). "A name is sacred": Archive Fever in Freud, Derrida, and Hubert Aquin. Mosaic: A Journal For The Interdisciplinary Study of Literature, 44, 125-140.

Sidgwick, H. 2011 [1874]. The Methods of Ethics, Some Texts From Early Modern Philosophy.

Sim, S. (2019). Post-Truth Scepticism \& Power. Palgrave Macmillan (Springer Nature).

St John 2013 [70-100 AD]. Holy Gospel of Jesus Christ according to Saint John. Evangelizo.org.

Van Assche, K., Raus, K., Vanderhaegen, B., \& Sterckx, S. (2019). "Capacity for Discernment" and Euthanasia on Minors in Belgium. Medical Law Review, 27, 242-266.

Veca, S. (2010). La filosofia politica. Edizioni Laterza.

Wittgenstein, L. (1958). The Blue and Brown Books. Basil Blackwell.

Publisher's Note Springer Nature remains neutral with regard to jurisdictional claims in published maps and institutional affiliations. 